\title{
30 YEARS OF BANK REGULATION IN HUNGARY
}

\author{
László Seregdi
}

\begin{abstract}
Bank regulation in Hungary has undergone massive changes in the past 30 years. It has taken several crises, and the lessons learned from these, for today's far-reaching system of rules governing the smallest details of bank operation and risks to emerge. This paper sets out to describe the historical frameworks for this. In 1989, when the Hungarian Banking Association was founded, bank regulation in Hungary was still somewhat basic and rudimentary. The $1991 \mathrm{Fi}-$ nancial Institutions Act brought about substantial changes to this situation. To some extent, even at this early stage the Pit. reflected the globally applied rules adopted from the recommendations of the Basel Committee and the European Union directives. Efforts to achieve European legal harmonisation already played an increasingly prominent role in domestic bank regulation prior to Hungary's EU accession in 2004. Today, however, the operation of banks is profoundly affected not only by EU regulations, but by the increasingly rapidly evolving and expanding supervisory methodology. Alongside the common EU rules, however, there is also scope for rule-making at national level, and Hungary actively makes use of this opportunity.
\end{abstract}

JEL codes: G21, K22, L51, N24, O16

Keywords: bank regulation, bank supervision, capital requirements

\section{REGULATION OF THE NASCENT DUAL BANKING SYSTEM}

At the launch of the two-tier banking system in 1987, the rules on the operation of banks only consisted of the most basic requirements. The requirements for prudent operation were fairly simple: a bank's balance sheet total was not permitted to exceed ten times its equity, its long-term investments could not exceed $60 \%$ of equity, and it was not allowed to grant credit to a single borrower in excess of $20 \%$ of its equity (PM, 1987). Financial supervision was already performed by the State Banking Supervisory Authority, although not yet independently, as the applicable Ministerial Council Decree stated the power to supervise banking activity was exercised by the minister of finance through the State Banking Supervisory Authority. And in 1989, the range of available supervisory tools was also fairly 
narrow. The simplicity of the regulation is illustrated by the fact that all the rules on establishment, prudent operation and supervisory procedures ran to only six pages of text.

This situation was changed slightly by Ministerial Council Decree 106/1989 on the Bank Supervision Conditions for Conducting Banking Activity and on the State Banking Supervisory Authority. This also introduced a regulatory tool whereby the supervisory authority could impose supervisory fines on a bank or its senior executives. The decree was also innovative in that it replaced the existing, leverage-based regulation with an adjusted balance sheet total calculation that applied certain basic risk weights (e.g. receivables from the central bank and the state received a multiplier of zero, and those from other banks a 0.2 multiplier). The 1989 MC decree also introduced the concept of doubtful receivables (e.g. exposures to loss-making debtors or receivables more than 60 days in arrears), the book value of which had to be reduced by 10 percent a year. Another new concept appearing in the decree was the supervisory fee payable by banks, which at that time was set at one tenth of a percent of annual interest and commission income (MC, 1989)

It should be borne in mind that all this took place in the period before the regime change and the widespread adoption of the internet, when it was nothing like as easy as it is now for the experts drafting the regulations to obtain suitable examples of international best practices. A positive aspect of the domestic regulation that deserves a mention is that the most important rules already reflected efforts to follow the example of more advanced Western European countries, although they were adopted into domestic practice in significantly simplified form. This is why the evolution of bank regulation in Hungary cannot be studied in isolation from the changes taking place at global level.

\section{KEY FACTORS SHAPING THE EVOLUTION OF BANK REGULATION IN HUNGARY}

The past 30 years of development of domestic bank regulation have been dominated by gradual convergence with the European regulatory environment. Adopting the laws of the European community was not yet compulsory in the 199os, but the rules set out in the various directives had an increasingly strong influence on Hungarian standards. The Financial Institutions Act passed in 1991 already set out to adopt the international system of norms, and in this context it also included two regulatory items that would have a major impact on the Hungarian banking system. The first was the stipulation of a minimum eight-percent solvency ratio, with the details of how this was calculated to be determined by a regulation of 
the banking supervisory authority. ${ }^{1}$ This framework, which was more or less in harmony with the EEC directive of the time, was what defined the minimum solvency requirements in Hungary.

\section{Solvency ratio versus Liquidity ratio}

The Hungarian name of the solvency ratio introduced in the EEC was fairly arbitrary. In 1991 it featured in the Pit. under the subheading of solvency, but was named the risk weighted asset ratio. The same indicator appears in 1996 in the newly drafted credit institutions act as the solvency ratio, but this name was changed liquidity ratio in the same statutory provision from 2003, to bring it into line with the official Hungarian translation of the EU directive on which it was based. The use of the term liquidity ratio, however, was misleading as the ratio does not indicate the credit institution's ability to meet short-term obligations (its liquidity), but its capital adequacy (solvency). From 1 July 2007, however, the logic of the Credit Institutions Act changed, and instead of setting an eight-percent liquidity ratio as the minimum requirement, it stated that a credit institution must always meet the capital requirement prescribed in separate rules for the various risk exposures, as well as the additional capital requirement stipulated for it by the supervisory authority. This logic remained after the CRR took effect, so today the laws no longer officially prescribe obligation to calculate the solvency ratio - although the National Bank of Hungary and analysts continue to require this - but states that the regulatory capital at a credit institution's disposal must always exceed the sum total of its capital requirements.

The other change to the Financial Institutions Act that had a major impact was the introduction of the requirement to set aside provisions for classified receivables. The rating of receivables and determination of the provisions was also regulated by a supervisory authority regulation. ${ }^{2}$ Although there was a protracted debate about whether the provisions generated in this way could be recognised by banks as items reducing the tax base, it was the imposition of these two requirements that eventually helped to uncover the problems that had been mounting up at Hungarian banks since the early 199os. Until that time, the banks had not been incentivised or forced to set aside provisions for their non-performing exposures, moreover the lack of regulations on non-accrued interest allowed them to state

1 Banking Supervisory Authority regulation 1/1992 (PK. 5.) on the Basic Principles and Rules for the Calculation of Capital Adequacy

2 State Bank Supervisory Authority regulation 3/1992 (PK. 10.) on the Criteria for Rating Receivables 
substantially higher profits than they had actually realised. All the general public saw of the banks' operation was that they were building ever bigger and more opulent new offices, and paying sky-high salaries to their executives. This is why an article published in the Financial Times in May 1993, calling two large banks in Hungary technically insolvent, came like a bolt out of the blue as far as public opinion was concerned. The exposure of the actual situation highlighted that fact that considerable problems had accumulated at Hungarian banks, which could only be resolved with bank, debtor and credit consolidation measures.

\section{Lack of rules on non-accrued interest}

Numerous problems had to be addressed during the switch to a two-tier banking system in Hungary. Especially prominent among these was the shortage of managers and employees with the requisite experience and expertise, as well as the weakness of the regulatory framework. For a long time there were no appropriate rules on capital requirements and provisioning, so the banks' financial statements did not reflect the actual situation. The most important of the missing rules was the requirement to state non-accrued interest, and in the absence of this obligation the banks stated revenues that had not actually been received. A bank with a non-performing debtor would recognise the interest payable on their loan as income, but was not under an obligation to set aside adequate provisions for this. Furthermore, under the accounting rules, all amounts received as loan repayments received from borrowers had to be recognised as interest payments first, with only the remainder stated as a principal repayment. Consequently, the banks were able to continue reporting high pre-tax profits with no basis in fact. The fictive profits generated in this way were taxed, paid out as dividend or added to capital in the form of retained earnings. As the first solution to the problem of non-accrued interest, from the end of 1993 a regulation of the Banking Supervisory Authority stipulated that provisions of $100 \%$ had to be set aside for interest receivables that have not yet been received; then, from 1996 the requirement to state nonaccrued interest was adopted in the accounting regulations. The seriousness of the problem is illustrated by the fact that the provisions set aside for interest revenues by banks at the end of 1993 accounted for around a fifth of all provisions generated by the banks (BAF, 1993).

Apart from the establishment and constant updating of the regulations, the early 1990s were also characterised by a rapid increase in the number of banks (in 1993 alone, six new banks were formed (BAF, 1993)), and competition between the banks also got under way - albeit only half-heartedly at first - in the retail bank- 
ing sector. And it was not only the external regulatory environment that needed development. During this period, supervisory on-site examinations revealed that the banks' internal regulations were also inadequate, so special rules had to be made to force an improvement in the standards of internal regulation. From 1994 the requirements relating to the owners and executives of banks were tightened up considerably. It became mandatory to establish an internal auditing unit, and the possibility of increasing capital by means of a non-cash contribution was ruled out (BAF, 1994/95).

\section{The universal banking system}

A recurring question in the 1990 os was whether or not banks should be able to engage in the direct provision of investment services. The most important reason for separating banking and investment activity was the Glass-Steagall Act applied in the United States from 1933. During the investigation into the causes of the Great Depression of 1929-33, the US regulators concluded that the crisis had been considerably worsened by the fact that the banks were also permitted to provide investment services. The question was first raised at the time of the reestablishment of the Budapest Stock Exchange in 1990. Banks were allowed at that time to provide services related to securities trading, but this right was abolished in 1993, and the banks only regained it in 1997. The first variant of the Financial Institutions Act still defined investment banks as a special type of bank, but these never became widespread in Hungary, and were later removed from the law (Pit., 1991). Even during this period, however, this activity did not have to completely segregated, as the larger banks could have subsidiaries that performed investment service activities. Therefore, although we can identify a period when the domestic banking system was not universal, this segregation was never as strict as it was in the USA, where the Glass-Steagal Act also prohibited banks from owning investment service providers.

From the mid-1990s onwards, the domestic legislative process was increasingly dominated by efforts to achieve full legal harmonisation with a view of joining the European Community. The need also emerged for a system of supervisory tools that were not only capable of reactively resolving existing issues with banks, but also provided the opportunity for preventive measures to stop the problems from arising in the first place. Accordingly, from 1994 the Pit. gave the supervisory authority greater freedom to determine when it could take emergency action, and the range of measures that it could implement was also expanded. The opportunity to appoint a manager was introduced, and it was from this that the 
role of supervisory commissioner, which remains in use to this day, evolved. This period, too, brought market innovations and a broadening of the scope of banks' activities. Accordingly, the strengthening of banks' off-balance-sheet activities made it necessary to determine the capital requirements for forward transactions more precisely. The banking supervisory authority regulation on the annual percentage rate was issued in the interest of tightening the consumer protection rules, and significantly improved the provision of information to customers prior to contract signing (BAF, 1995/96). By the second half of the 1990 it had become customary for banks to try and reduce their reported risks by selling loans and assets from their portfolio with deferred payment and a buyback obligation. For this reason, strict provisioning requirements had to be introduced for these items (ÁPTF, 1996).

From 1997, with the passing of the Credit Institutions Act ${ }^{3}$ (Hpt.), further steps were taken towards legal harmonisation with the EU, which made it necessary to introduce numerous new definitions (e.g. financial service provision instead of financial-institution activity, credit institutions instead of financial institutions, limits on large exposures instead of large loans). Another event associated with the Hpt. was the separation of the incorporation permit and operating license for credit institutions, resulting in a two-step authorisation process. The Hpt. also replaced the previous notification requirement with an obligation to obtain supervisory authority approval for the appointment of senior executives at a credit institution. Under the Hpt., the banks regained the entitlement to provide investment services, and thus the Hungarian banking system became universal again (ÁPTF, 1997). Concurrently with this, the banking supervisory authority and the securities supervisory authority were merged. Home saving funds and mortgage credit institutions were brought under the regulations as new types of credit institution.

The year 2000 saw another merger of supervisory authorities, as the bank and capital markets supervisory authority was augmented with the insurance and pension fund supervisory authority. This integration of the supervisory bodies made it possible for the regulatory processes of financial institutions with similar financial risks to converge. At the same time, particular attention was also devoted to elaborating the detailed rules of consolidated supervision. This approach, which was close to international practice, treated group-level compliance as being at least as important as compliance at individual company level.

From 2001 a new tool was introduced in the form of supervisory recommendations, which were later augmented with methodological guidelines, bulletins and executive memorandums. These new tools were not only suitable for 
communicating the domestic supervisory expectations, but also as a vehicle for adopting the guidelines of the organisation created to oversee the harmonisation of EU bank supervision (CEBS, later the $\mathrm{EBA}^{4}$ ). The early 2000 s was essentially given over to the preparations for joining the European Union and, within this framework, the efforts to achieve full legal harmonisation.

Bank regulation in Hungary in the first decade of the 2000 s was mainly notable for the absence of regulatory tools that could have prevented the rapid growth in retail foreign currency loans experienced between 2003 and 2008. As a consequence of this, the banks not only passed on the exchange rate risk to their customers, but were in such a dominant position that they were able to unilaterally change the interest rates and various other charges (Balog-Nagy, 2013). This situation, which appeared very favourable for the banks, backfired on them spectacularly as a result of the changes resulting from the global financial crisis, leading to a rapid increase in the proportion of non-performing loans. From a regulatory perspective, the first half of the 2010 s were chiefly devoted to reducing the banks' economic and legal dominant position - providing consumers with significantly stronger rights than before - and to making the banking sector share some of the losses that it had originally tried to avoid by passing them on to consumers. Besides this, it was also necessary to make rules that would prevent similar problems reoccurring in future. These regulatory measures included the exchange rate cap, the prohibition on unilateral contract amendments that are disadvantageous to the customer, the permitting of early repayment in full, introduction of debt brake limits (loan-to-income and loan-to-value ratios), as well as a considerable tightening of the conditions for retail foreign currency lending. The fallout from retail foreign currency loans had a long-lasting and severe impact on the Hungarian banking sector. The only positive outcome of this was that it clearly shed light on the problematic fact that, previously, consumer protection regulations had been exceptionally weak in Hungary. It became clear that consumer protection also had to be bolstered in order to prevent risks building up again in the future. As a result of this, the present banking consumer protection rules are considerably more robust than they would be had the foreign currency lending crisis not occurred.

From 2013, the Hpt. was reworked, retaining its original name but with sweeping changes to its content. The amendments were primarily needed because of the Basel III guidelines and the new EU directives on their implementation; and they also created harmony with the CRR rules applicable from 1 January 2014. Consequently, a substantial proportion of the prudential regulations were taken out of the Hpt. as they were now contained in the EU regulations.

${ }_{4}$ CEBS - Committee of European Banking Supervisors; EBA - European Banking Authority 


\section{OPPORTUNITIES FOR BANK REGULATION AT NATIONAL LEVEL}

Since 2014 the EU has steadily moved towards the regulation of prudential issues by means of directly applicable regulations, allowing the member states have relatively few opportunities to make rules at national level. The most important aspects of prudential regulation, therefore, are already a part of the EU legislation. In practice, however, several member states - including Hungary - continue to apply numerous rules made at national level. In Hungary these are take the form of the options and national discretions featured in the CRD/CRR/BRRD 5 and in the macro-prudential rules, and the laws relating to issues that are not regulated at EU level.

The EU directives and regulations allow member states to depart from the general rules on a number of points. A substantial proportion of these national 'discretions' were related to the introduction of the CRR, and consisted of transitional arrangements that member states could use to alter the length of time given to banks to fulfil the higher-level requirements of the CRR. These particular transitional arrangements were only in effect in Hungary for two years, from 2014 to 2015; and today most of the transitional arrangements in the CRR have expired. However, the CRR still provides for decisions that can be made at national level ${ }^{6}$, especially those relating to the minimum initial capital, exemptions from large exposure limits, certain detailed rules on the liquidity coverage ratio (LCR), the risk weighting of exposures secured with real estate, and the treatment of investments in insurance companies for the purpose of calculating regulatory capital. In Hungary, the most important of these are the opportunity for the Credit Institutions Act to specify a lower initial capital requirement for cooperative credit institutions, and the permitted exemptions from the large exposure limit.

Retrospective studies have shown that one of the causes of the global financial crisis was that bank supervision bodies concentrated primarily on the situation of individual banks. This means that risks affecting the system as a whole were not properly identified and managed. For this reason, after the crisis major steps were

\footnotetext{
5 CRD (Capital Requirements Directive) - Directive 2013/36/EU of the European Parliament and of the Council of 26 June 2013 on access to the activity of credit institutions and the prudential supervision of credit institutions and investment firms.

CRR (Capital Requirements Regulation) Regulation No 575/2013/EU of the European Parliament and of the Council of 26 June 2013 on prudential requirements for credit institutions and investment firms.

BRRD (Bank Recovery and Resolution Directive) - Directive 2014/59/EU of the European Parliament and of the Council of 15 May 2014 establishing a framework for the recovery and resolution of credit institutions and investment firms.

6 On its website, the EBA gives a detailed description of the options and national discretions applied by the member states: https://eba.europa.eu/supervisory-convergence/supervisory-disclosure/ options-and-national-discretions.
} 
taken at global, EU and domestic level in relation to macro-prudential regulation and supervision. Macro-prudential regulation is especially important in the EU, because it creates the opportunity to identify the risks that are typical of a given country's financial system, and for the macro-prudential authorities to create - at national level - the appropriate rules and requirements to deal with them. One of the key areas for macro-prudential regulation is determining the various capital buffers, where the combined buffer requirement has to be calculated taking into account the anti-cyclical and global capital buffers, the capital buffers relating to other systemically important credit institutions and systemic risks, together with the capital conservation buffer. In Hungary, the role of the macro-prudential supervisory authority is fulfilled by the Central Bank of Hungary, and in this capacity it has already determined the buffer requirements relating to other systemically important credit institutions, and successfully applied the systemic risk buffer to ensure the quickest possible reduction in substandard project loans. Macro-prudential regulation and supervision, however, goes far beyond the setting of capital buffers, and can extend to any systemic risk with the potential to endanger financial stability. The Central Bank of Hungary has made use of its authority in this area to create numerous macro-prudential rules aimed at preventing any future build-up of material systemic risks. These include the 'debt brake' rules serving to prevent excessive credit growth, as well as the tools for managing liquidity and financing risks, namely the foreign exchange funding adequacy ratio (FFAR), foreign exchange coverage ratio (FECR), Mortgage Financing Adequacy Ratio (MFAR) or interbank financing ratio (IFR). The importance of macro-prudential regulation stems not only from its proven ability to prevent the built-up of future system risks, but also from that fact that it allows rules to be made at national level in cases where the CRR offers increasingly few opportunities to do so.

The currently effective Hpt. contains a few more special rules, relating to the regulation of banks, which have not been separately determined at EU level. The 1991 Financial Institutions Act already imposed a general reserve requirement, and from 1997 the only change was to specify that each credit institution must place $10 \%$ of its after-tax profit in the general reserve (unless the Central Bank of Hungary grants an exemption based on the strength of its high capital adequacy). There is also a long tradition of capping a credit institution's total direct and indirect investments at 100 percent of regulatory capital, which is also not an EU requirement but was already stipulated in the 1991 Pit.. Another rule peculiar to Hungary is the limit on a credit institution's investments in real estate. The ceiling for this was still set at $15 \%$ of regulatory capital in the Pit., and $5 \%$ in the

7 The upper limit for total investments rose to $125 \%$ with effect from 1 January 2019. 
present legislation. An interesting contradiction between the Hungarian and EU regulation is that the Credit Institutions Act prohibits a credit institution from taking on risk in transactions with the purpose of financing the acquisition of shares in the bank. The CRR does not restrict this; but on the other hand it does not permit the credit institution to recognise such equity interests as a part of its own funds if their acquisition was financed by the bank itself.

The above examples are additional evidence that even with EU membership and against the backdrop of the EU's increasingly centralised system of bank regulation, there is still a need, and opportunities, for national regulatory bodies to actively make use of the opportunities available to them, and align the rules on banks with the characteristics of the domestic market and risks.

\section{THE PRESENT-DAY CHALLENGES OF BANK REGULATION}

The regulation of banking today is constantly evolving increasingly complex. This can make life more difficult both for the banks and for the supervisory authorities, who need to perform their tasks as effectively as possible in a rapidly changing environment. The regulatory responses to the global financial crisis are still a work in progress, with the elaboration of many details still currently in the pipeline. The biggest domestic regulatory challenge of the near future will be the local implementation of the amendments currently being made to the CRD and BRRD. These will substantially alter the system for determining the supervisory additional capital requirement, and will also introduce supervisory capital guidance as a new regulatory tool. In the case of the latter, the supervisory authority, taking the results of the stress tests into consideration among other factors, determines for every bank the additional capital that it expects to be made available in addition to the Pillar 2 capital requirement. The MREL (Minimum Requirement for Eligible Liabilities) regulations will also be finalised in the CRR and BRRD, based on which the Central Bank of Hungary, as the recovery and resolution authority, determines the extent of eligible liability a bank needs to have in addition to the capital requirements, in order to cover the losses in the event of a crisis management procedure. In addition, the capital requirements applied to date will be supplemented with a new, additional requirement relating to the leverage ratio. 


\section{Leverage ratio: the higher the better!}

By its original definition, the leverage ratio measures the proportion of a business's total assets/activity to its equity. Accordingly, in the traditional approach, the higher leverage a company has, the riskier it is, because its activities are financed with a high proportion of external funds that carry a repayment obligation. Banks traditionally operate with high leverage, and the global financial crisis demonstrated that regardless of whether a bank had a satisfactory capital adequacy ratio, it was primarily the institutions operating with high leverage that got into trouble. However, the new guidelines drawn up by the Basel Committee, which will soon take effect in the EU in the form of a regulation, define the leverage ratio not as total assets/equity, but as the ratio of Tier 1 capital to risk exposures adjusted for correction factors, and stipulates that it must always be at least $3 \%$. So while under the traditional approach the higher the leverage the riskier the bank, with the new ratio, a higher figure indicates safer bank operation.

The current proposed regulatory amendments to the CRD and CRR do not yet incorporate the changes made by the Basel Committee at the end of 2017 with the aim of finalising the Basel III framework. These will be included in a later EU legislation process, and are expected to take effect from 2022. The output floor to be introduced for banks that use the internal model approach for calculating the capital requirement of credit risk, the increase in the sensitivity of the standard approach for credit risk, the narrowing of the range of applications of internal models and the reworking of the capital requirement calculation for operational risk, will all improve the stability of the domestic banking system.

The European Union has also started to draw up stand-alone regulations in two other areas that will have a substantial impact on the Hungarian banking sector. Perhaps the most important of these is the new system of rules to be elaborated in respect of non-performing loans, with the aim of preventing non-performing exposures from accumulating at banks again. To this end, a new set of rules will have to established, which requires banks to recognise impairment at an increasingly high rate after the exposure becomes non-performing, to cover the expected losses. Another part of the NPL package is incentives to develop the NPL secondary market, facilitating better recovery of the receivables, and providing member states with technical guidance on the establishment of national asset management companies.

The other significant regulatory amendment taking shape at the present time is aimed at placing emphasis on sustainable finance. The EU intends to use bank 
regulation as one of the means of encouraging investments in the European Union that are in line with the environmental objectives, and reduce the burden on the environment. To achieve this, numerous amendments are expected, in particular the categorisation of investments in terms of the extent to which they serve environmental interests, while prudential regulations will permit the use of a more favourable risk weight for the financing of investments of this nature. Systemically important banks, meanwhile, will have to disclose additional information about the extent of their exposure to the elevated risks resulting from climate change, and how they are managing them.

Although they are not discussed in detail here, we should also mention the steps taken and planned in the interest of achieving capital markets union in the EU (secured bonds, SME finance, ESN), which will also have an indirect effect on the operating environment of banks in Hungary.

\section{SUMMARY}

Bank regulation in Hungary has undergone massive changes over the past 30 years. It has taken several crises, and the lessons learned from these, for today's far-reaching system of rules governing even the smallest details of bank operation and risks to emerge. Alongside the comprehensive rules of the European Union, however, there is still a need for rules to be made at national level, taking local characteristics into account, which may be able to prevent a future build-up of excessive risks. The responses of international regulators to the global financial crisis are still a work in progress. Given the rapid pace of innovation and evolution of banking operations, they will probably continue to have a role in ensuring that regulation and supervision, combined, are capable of preventing excessive losses in the future. Exposure to risk, and the attendant potential losses, is a natural feature of banking activity; and as such it should not be avoided, but maintained within the appropriate framework. For this reason, regulators constantly need to maintain a healthy balance between avoiding unnecessary over-regulation and unwarranted increases in the costs of regulation, and establishing frameworks for reducing the probability of events that threaten financial stability to a minimum. Until now, in most cases, each of the main milestones in the development of bank regulation was closely associated with a specific crisis event that required immediate regulatory intervention (e.g. Herstatt Bank, BCCI, Barings, retail foreign currency lending). Experience tells us that the periodic occurrence of crises is unavoidable, so it is in the best interests of every actor in the financial markets for the next crisis to find a Hungarian banking sector that is prepared, solvent and capable of weathering stress situations. 


\section{REFERENCES}

ÁPTF $(1996,1997)$ : Reports of the Hungarian Money and Capital Markets Supervisory Authority.

BAF (1993, 1994/95, 1995/96): Annual reports of the State Banking Supervisory Authority.

Balog Á. - Nagy M. (2013): The Dominant Position of Banks in the Foreign Currency Lending Problem [A bankok erőfölénye a devizahiteles-problémában]. https://www.mnb.hu/letoltes/abankok-erofolenye-a-devizahiteles-problemaban-1.pdf

FÁBIÁN G. - VIRÁG B. [eds.] (2018): Banks in History: Innovations and Crises, [Bankok a történelemben: Innovációk és válságok] MNB.

Seregdi L. (2016): The Practice of International Cooperation Between Financial Supervisory Authorities, the Necessity and Potential Directions of Further Development [A pénzügyi felügyeletek közötti nemzetközi együttműködés gyakorlata, a továbbfejlesztés szükségessége és lehetséges irányai] $\mathrm{PhD}$ thesis, University of Kaposvár.

\section{Laws and regulations}

Hpt. (1996): Act CXII of 1996 on Credit Institutions and Financial Enterprises.

Hpt. (2013): Act CCXXXVII of 2013 on Credit Institutions and Financial Enterprises.

MT (1989): Ministerial Council Decree 106/1989 on the Bank Supervision Conditions of Conducting Banking Activity and on the State Banking Supervisory Authority.

Pit. (1991): Act LXIX of 1991 on Financial Institutions and their Activities.

PM (1987): Ministry of Finance Decree 43/1987 (IX. 8.) on Certain Issues Relating to State Banking Supervision. 